\title{
Environmental effects on pre-weaning traits in Santa Gertrudis cattle $^{1}$
}

\author{
Efeitos ambientais sobre características da pré-desmama em \\ bovinos da raça Santa Gertrudis
}

\author{
Bruna Silva Marestone ${ }^{2}$; Carolina Amália de Souza Dantas Muniz ${ }^{3 *}$ \\ Edson Luis de Azambuja Ribeiro ${ }^{3}$; Sandra Maria Simonelli ${ }^{3}$
}

\begin{abstract}
We aimed to evaluate environmental effects on pre-weaning traits of Santa Gertrudis cattle. We used 213 standardized records for adjusted 205-day weight at weaning (W205), average daily gain from birth to weaning (AGD), and number of days to gain $160 \mathrm{~kg}$ from birth to weaning (D160), obtained from the Santa Gertrudis Breeders' Association for animals born between 1990 and 1997. The files were edited with information regarding cow age at calving (CAC) and contemporary group (CG),for which the effects of year and season of birth, animal category, herd, and sex were considered. It was observed that cow age at calving, which had linear and quadratic effects, and effect of contemporary group were significant $(\mathrm{P}<0.0001)$ for the evaluated traits. Estimated averages were $198.05 \pm 40.64 \mathrm{~kg}, 0.790 \pm$ $0.198 \mathrm{~kg} \mathrm{day}^{-1}$, and $288.05 \pm 67.18$ days for W205, ADG, and D160, respectively. Males were 4.67 $\mathrm{kg}$ heavier $(197.17 \mathrm{~kg})$ than females, on average. Regarding the animal category effect, the classified females were $2.3 \%$ heavier than the unclassified males, on average. On average, animals born in the dry season were $1.6 \%$ lighter than those born in the rainy season $(197.18 \mathrm{~kg})$. Thus, environmental effects are important and should be considered in any analysis model.
\end{abstract}

Key words: Contemporary group. Precocity of growth. Selection criteria.

\section{Resumo}

O objetivo deste estudo foi avaliar os efeitos ambientais sobre as características da pré-desmama em bovinos da raça Santa Gertrudis. Foram utilizados 213 registros de peso à desmama padronizado aos 205 dias (P205), ganho médio diário do nascimento à desmama (GMD) e número de dias para ganhar $160 \mathrm{~kg}$ do nascimento até a desmama (D160), oriundos da Associação dos Criadores de Santa Gertrudis, de animais nascidos no período de 1990 a 1997. Os arquivos foram editados com as informações da idade da vaca ao parto (IVP) e grupo de contemporâneos (GC) que considerou os efeitos de ano e estação de nascimento, categoria animal, rebanho e sexo. Por meio dos resultados obtidos observou-se que a idade da vaca ao parto, efeitos linear e quadrático e o grupo de contemporâneos foram significativos $(\mathrm{P}<0,0001)$ para as características avaliadas. As médias estimadas foram de 198,05 $\pm 40,64 \mathrm{~kg}, 0,790 \pm$ $0,198 \mathrm{~kg} \mathrm{dia}^{-1} \mathrm{e} 218,05 \pm 67,18$ dias para P205, GMD e D160, respectivamente. Os machos foram 4,67 $\mathrm{kg}$ mais pesados $(197,17 \mathrm{~kg})$ do que as fêmeas. No efeito de categoria animal as fêmeas selecionadas

\footnotetext{
1 Trabalho de Conclusão de Curso da primeira autora, como parte das exigências para a obtenção do título de Zootecnista, Universidade Estadual de Londrina, UEL, Londrina, PR.

2 M.e em Ciência Animal, Universidade Federal do Mato Grosso do Sul, UFMS, Campo Grande, MS, Brasil. E-mail: brunamarestone@gmail.com

3 Profs., Departamento de Zootecnia. Centro de Ciências Agrárias, Universidade Estadual de Londrina, UEL, Londrina, PR, Brasil.E-mail: muniz@uel.br; elar@uel.br; simonelli@uel.br

* Author for correspondence
} 
mostraram-se 2,3\% superiores aos machos. Animais nascidos na estação da seca foram 1,6\% mais leves em relação aos que nasceram nas águas $(197,18 \mathrm{~kg})$. Assim, as avaliações dos efeitos ambientais tornam-se importantes e devem ser consideradas no modelo de análise.

Palavras-chave: Critérios de seleção. Grupo de contemporâneos. Precocidade de crescimento.

\section{Introduction}

The opening of new markets, accompanied by human population growth, exposes beef producers to the challenge of intensifying animal production, to produce more in less time, without decreasing product quality or economic efficiency.

According to Corrêa et al. (2006), one of the tools to increase productive performance in herds is animal genetic improvement through selection of genetically superior animals, with the goal of genetic improvements in future generations. To reach this goal, characteristics of economic interest were studied, and the animal husbandry environment was evaluated.

In beef cattle, pre-weaning traits are of great economic importance. Pereira and Muniz (2013) stated that at this stage, the first data on the performance of the animal are obtained and it is possible to evaluate both the genetic potential of growth of the calf and the maternal ability of the cow. Some characteristics can be evaluated during this breeding phase, such as the adjusted 205-day weight at weaning (W205), average daily gain from birth to weaning (ADG), and number of days after birth for the animal to gain $160 \mathrm{~kg}$ (D160).

W205 is one of the first factors obtained to evaluate the performance of the animal. To make comparisons among weights of weaned calves of different ages, it is necessary to make corrections between the ages, such that there are no advantages or disadvantages for those who were weaned at a greater or lesser age. Cardoso et al. (2001) explained that the calf age adjustments at weaning are most often completed by the average daily gain for the standard age of 205 days and that these adjustments assume linear growth. ADG is a feature of great importance, because fast growth is a desirable characteristic in beef cattle; thus, animals with higher growth capacity need less time to reach the age of slaughter (SARMENTO et al., 2003).

Similar to ADG, according to Fries et al. (1996), the D160 provides breeders with a shorter time to produce certain market units rather than waiting to obtain heavier animals. The identification and selection of fast-growing animals at this stage have been used by farmers to improve the efficiency of breeding systems (CORRÊA et al., 2006).

According to the Brazilian Association of Santa Gertrudis Breeders (ACSG, 2018), the Santa Gertrudis breed was developed in 1929 by the owners of the King Ranch Farms in Texas, USA, with the goal of obtaining beef cattle that would reunite high productivity and rusticity. They are adapted to southern United States climatic conditions. The breed was introduced to Brazil in 1953 by the same breeders of the King Ranch Farms, including 34 males and 225 females.

The breed was the result of the programmed crossbreeding between zebuine and taurine animals of the Brahman and Shorthorn breeds, respectively, being composed of 3/8 Brahman $+5 / 8$ Shorthorn (LUCHIARI FILHO; MOURÃO, 2006). There are few published studies regarding the Santa Gertrudis breed in Brazil. The generation of scientific information about this breed is of great importance because the breed presents good adaptability to Brazilian conditions.

It should be noted that several factors may interfere with the development and expression of genetic potential. In the pre-weaning phase, performance traits, W205, ADG, and D160 may be influenced by environmental factors, such as cow age at calving, year of birth, season of birth, sex, herd, and diet. In this context, the objective of this 
study was to evaluate the environmental effects of pre-weaning traits on Santa Gertrudis cattle.

\section{Material and Methods}

The data used came from zootechnical records for Santa Gertrudis cattle regarding animals registered by the Santa Gertrudis Breeders' Association (ACSG) from 1990 to 1997 by several breeders. The animals were weighed every four months, as often as possible, and they were classified into three categories: classified females (CF), unclassified males, that were young or without technical approval (M), and unclassified females (UF).

A new file was prepared with the following information: animal number, animal category, date of birth, mother number, mother's date of birth, weight at birth, and weighing dates. The files were evaluated for consistency and the animals that did not have complete information were eliminated. Also, adjustments were made as follows:

Adjusted 205-day weight at weaning in $\mathrm{kg}$ :

$$
\mathrm{W} 205=\frac{\mathrm{WW}-\mathrm{BW}}{\mathrm{CA}} \times 205+\mathrm{BW}
$$

Average daily gain up to weaning, in $\mathrm{kg}_{\text {day }}{ }^{-1}$ :

$$
\mathrm{ADG}=\frac{\mathrm{WW}-\mathrm{BW}}{\mathrm{CA}}
$$

Days to gain $160 \mathrm{~kg}$ from birth to weaning, in days:

$$
\mathrm{D} 160=\frac{160}{\mathrm{ADG}}
$$

where:

$\mathrm{WW}=$ Weaning weight;

$\mathrm{BW}=$ Birth weight;

$\mathrm{CA}=$ Calf age (days);

$160=$ Expected weight at the end of the period in $\mathrm{kg}$;

$\mathrm{ADG}=$ Average daily weight gain from birth to weaning, in $\mathrm{kg}$.

An average of $35.7 \mathrm{~kg}$ of weight at birth was considered for all animals because of the absence of this record for many individuals. This average value was generated from the weights in the files in an effort to eliminate as few observations as possible.

With the adjusted 205-day weight, ADG and D160 were calculated. Contemporary groups were formed considering the effects of year of birth, season of birth, rainy season (October to March) or dry season (April to September), sex, animal category, and breeder.

The cow age at calving (CAC) was approximated with whole numbers ranging from two to 13 years, and older animals were eliminated. This value was considered a covariate with linear and quadratic effects. Contemporary groups containing less than two observations were deleted from the analysis file.

To compare the performance of the animals, the observations were analyzed by the Least Squares Method, by the following model:

$$
\mathrm{Y}_{\mathrm{ijk}}=\mu+\mathrm{GC}_{\mathrm{i}}+\mathrm{b}_{1}\left(\mathrm{X}_{\mathrm{ijk}}\right)+\mathrm{b}_{2}\left(\mathrm{X}_{\mathrm{ijk}}\right)+\mathrm{e}_{\mathrm{ijk}}
$$

where:

$\mathrm{Y}_{\mathrm{ijk}}=$ observation (performance) of the k-th animal; $\mu=$ general average;

$\mathrm{GC}_{\mathrm{i}}=$ fixed effect of the $\mathrm{i}$-th contemporary group $(\mathrm{i} \leq 69)$;

$b_{1}$ and $b_{2}=$ coefficients of linear and quadratic regression, respectively;

$X_{\mathrm{ijk}}=$ fixed effect of the $\mathrm{j}$-th cow age at calving in years $(1=2 \ldots .13)$;

$\mathrm{e}_{\mathrm{ijk}}=$ random error associated with each observation ijk. 
Based on the averages estimated for the 69 contemporary groups formed, the averages for year of birth, season of birth, sex, animal category, and breeder were calculated.

To estimate the effect of CAC on calf performance, the following equation was used:

$$
\hat{y}=b_{0}+b_{1} x+b_{2} x^{2}
$$

where:

$\mathrm{b}_{0}=$ intercept;

$b_{1}$ and $b_{2}=$ coefficients of linear and quadratic regression, respectively;

$\mathrm{x}=$ cow age at calving, in years.

The intercept $\left(\mathrm{b}_{0}\right)$ was obtained as follows:

$$
\mathrm{b}_{0}=\mu-\mathrm{b}_{1} \overline{\mathrm{x}}-\mathrm{b}_{2} \overline{\mathrm{x}}^{2}
$$

where:

$\mu=$ general average estimated by the model; $b_{1}$ and $b_{2}=$ coefficients of linear and quadratic regression, respectively;

$\overline{\mathrm{x}}=$ weighted average of the cow age at calving, in years;

$\overline{\mathrm{x}}^{2}=$ weighted mean square of the cow age at calving.

Thus, the regression equation can be represented as:

$$
\hat{y}=\mu-b_{1} \bar{x}-b_{2} \bar{x}^{2}+b_{1} x+b_{2} x^{2}
$$

\section{Results and Discussion}

The values obtained for W205 (Table 1) were lower than those obtained by Ferraz et al. (2000) of $221.11 \mathrm{~kg}$, Taylor (2006) of 247.7 and $254.7 \mathrm{~kg}$, and Tholon et al. (2010) of $213.29 \mathrm{~kg}$ for animals of the same breed.

Table 1. Average ( \pm standard deviations) and maximum and minimum values for weight adjusted for weaning (W205), average daily gain from birth to weaning (ADG), and number of days for the animal to gain $160 \mathrm{~kg}$ from birth to weaning (D160).

\begin{tabular}{cccccc}
\hline Traits & N & Average \pm SD & Minimum & Maximum & CV (\%) \\
\hline W205 (kg) & 213 & $198.05 \pm 40.64$ & 105.76 & 308.92 & 11.23 \\
ADG (kg day ( $\left.^{-1}\right)$ & 213 & $0.790 \pm 0.198$ & 0.340 & 1.33 & 13.72 \\
D160 (days) & 213 & $218.05 \pm 67.18$ & 20.18 & 470.15 & 16.88 \\
\hline
\end{tabular}

$\mathrm{N}=$ Number of observations; $\mathrm{SD}=$ Standard Deviation; $\mathrm{CV}=$ Coefficient of Variation.

Comparison with other breeds yielded a similar result in the study of Ribeiro et al. (2009), who analyzed data for Nelore animals, and observed an average of $198.77 \mathrm{~kg}$. Guimarães et al. (2003) and Fialho et al. (2015) evaluated the weight at 205 days for Tabapuã and Nelore animals, respectively, and obtained lower values (170.35 and $175.59 \mathrm{~kg}$ ) than in this study. However, it should be emphasized that animals of zebuine origin have, in general, lower average values in relation to animals that present taurine breeds in their genetic composition, as in the case for Santa Gertrudis.
The estimated general average for ADG was $0.790 \pm 0.198 \mathrm{~kg} \mathrm{day}^{-1}$, which is higher than that found by Oxford et al. (2009) of $0.676 \mathrm{~kg} \mathrm{day}^{-1}$ and lower than that of Taylor (2006) and Ferreira et al. (2010) of 1.00 and $0.840 \mathrm{~kg} \mathrm{day}^{-1}$, respectively, for Santa Gertrudis animals. This average was close to that found by Martins et al. (2000) of $0.771 \mathrm{~kg} \mathrm{day}^{-1}$ for Nelore animals. However, lower average values were obtained by Lopes et al. (2009) with an ADG of $0.701 \mathrm{~kg} \mathrm{day}^{-1}$ for Brangus animals. Fialho et al. (2015) observed an ADG of 0.650 and $0.700 \mathrm{~kg} \mathrm{day}^{-1}$ for Nelore and Brangus, respectively. 
The animals of the Santa Gertrudis breed averaged $218.05 \pm 18.67$ days to gain $160 \mathrm{~kg}$ from birth to weaning, a time shorter than that found by Gemin et al. (2004) of an average of 285 days for Guzerá animals. Santos et al. (2011), Pereira and Muniz (2013), Ferreira et al. (2014), and Fialho et al. (2015) analyzed data from Nellore animals and found averages of 237, 306, 233, and 248 days, respectively. Thus, the Santa Gertrudis breed in this study gained $160 \mathrm{~kg}$ from birth to weaning in a shorter period of time.

The contemporary groups significantly influenced the traits studied (Table 2), indicating that it is necessary to consider these sources of variation when comparing the performance of animals. Tholon et al.
(2010) classified animals into contemporary groups consisting of animals born in the same year, season of birth, farm, and sex to evaluate the environmental effects on different growth traits of Santa Gertrudis cattle raised in Brazil. The authors observed that the environmental effects considered had significant effects on all growth variables from birth to 24 months of age.

CAC presented a linear and quadratic effect on the pre-weaning characteristics (Table 2). Figures 1, 2, and 3 represent the effect of CAC on W205, ADG, and D160, respectively. It was observed that cows whose calving occurred at the age of seven years weaned the heaviest calves $(209.59 \mathrm{~kg})$. Therefore, it is suggested that the cull of cows occurs after that age.

Table 2. Degrees of freedom and mean squares for sources of variation included in the model adjusted for weight at weaning (W205), average daily gain from birth to weaning (ADG), and number of days for the animal to gain $160 \mathrm{~kg}$ from birth to weaning (D160).

\begin{tabular}{ccccc}
\hline \multirow{2}{*}{ Source of Variation } & $\begin{array}{c}\text { Degrees of } \\
\text { freedom }\end{array}$ & W205 (kg) & ADG (kg day $\left.\mathbf{~}^{-1}\right)$ & D160 (days) \\
\cline { 3 - 5 } & 68 & $3577.3438^{*}$ & $0.085^{*}$ & $9548.17^{*}$ \\
Contemporary Group & 1 & $8970.2093^{*}$ & $0.21^{*}$ & $24.005 .38^{*}$ \\
Cow age at Calving (L) & 1 & $9695.5401^{*}$ & $0.23^{*}$ & $25.327 .28^{*}$ \\
\hline Cow age at Calving (Q) & 138 & 602.2782 & 0.014 & 1722.30 \\
\hline Residual & - & 75.66 & 75.66 & 74.31 \\
\hline $\mathbf{R}^{\mathbf{2}}(\%)$ & &
\end{tabular}

Figure 1. Effect of cow age at calving on weight corrected at 205 days of age (W205, in $\mathrm{kg}$ ) of Santa Gertrudis cattle.

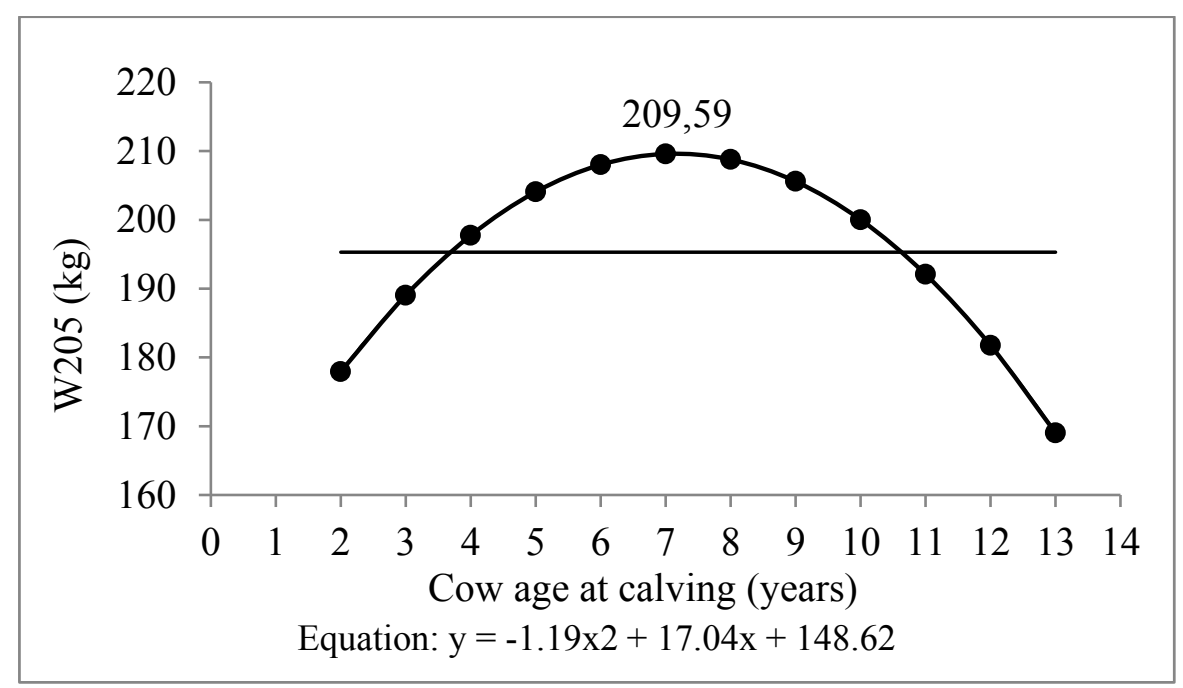


Figure 2. Effect of cow age at calving on the average daily gain from birth to weaning (ADG, in $\mathrm{kg} \mathrm{day}^{-1}$ ) of Santa Gertrudis cattle.

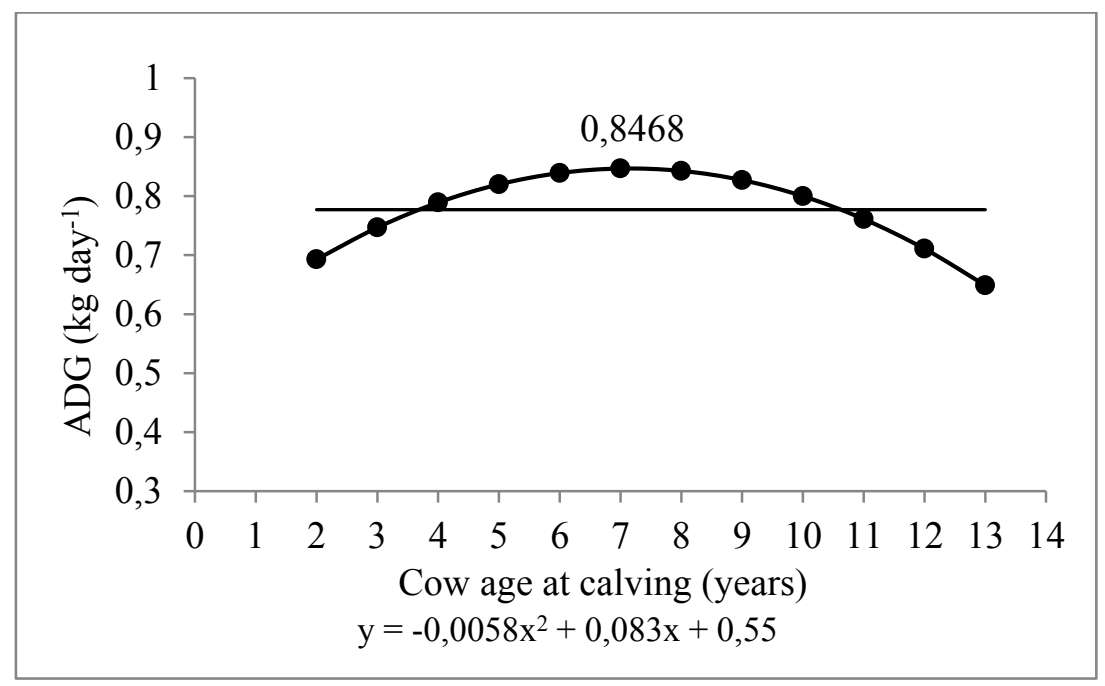

Figure 3. Effect of cow age at calving on number of days to gain of $160 \mathrm{~kg}$ from birth to weaning (D160, in days) in Santa Gertrudis cattle.

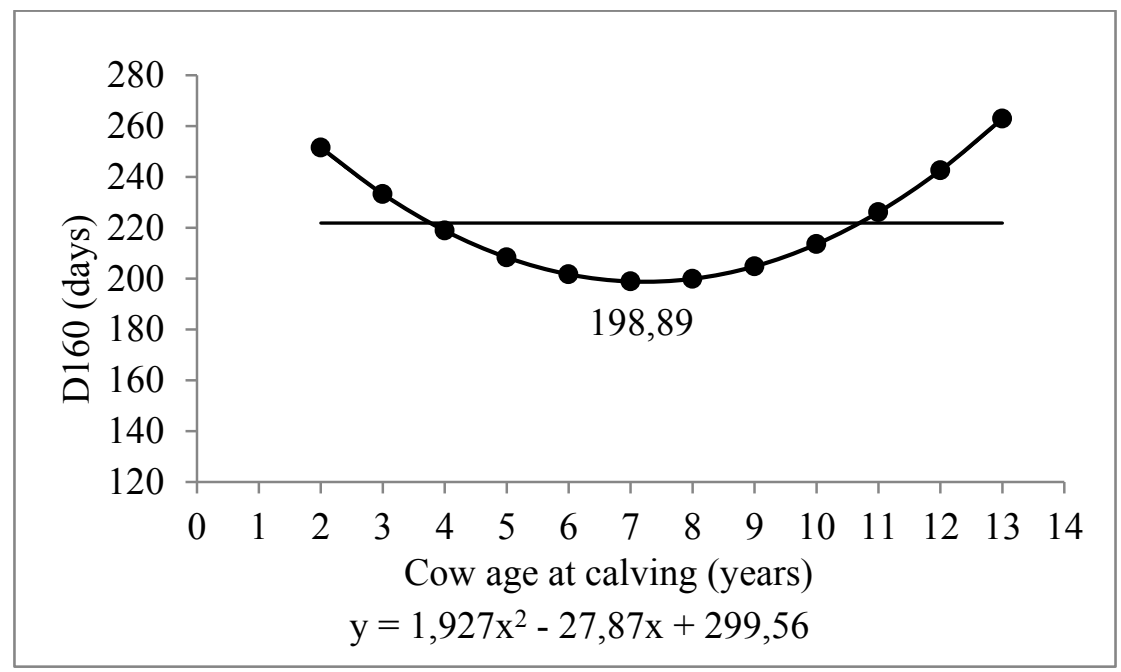

The older and younger cows had calves with lower performance for the traits studied. It is believed that much of the maternal influence may be caused by changes in milk production capacity over the course of years. According to Bocchi and Albuquerque (2005), many young or very old cows tend to wean lighter calves. The authors explained that the effect of cow age and/or calving order is closely linked to calf development in the pre-weaning period, mainly because of maternal ability. In addition, other variations may also alter the living environment of the animals and influence their performance characteristics, such as variation in pasture supply, climate, soil, and management, among other factors. Some studies have also identified the influence of cow age on calving performance on pre-weaning calves (TEIXEIRA; ALBUQUERQUE, 2003; BOCCHI et al., 2004).

Table 3 shows that contemporary groups with animals born in 1995 were weaned heavier (246.74 
$\mathrm{kg})$, had higher values of ADG (1.028 $\left.\mathrm{kg} \mathrm{day}^{-1}\right)$, and the lowest D160 (160.30 days). For the other years, there were oscillations in the averages, and 1993 was the year that the animals weaned with lower weights $(180.92 \mathrm{~kg})$, had the lowest ADG $\left(0.707 \mathrm{~kg} \mathrm{day}^{-1}\right)$ and higher D160 values (246.57 days). Possibly, the oscillations among the averages are caused by variation in climate, management, pasture quality, or rainfall, by which the animals were affected and could have influenced their performance. There may also be a relationship with the management of the animals, where in some years the number of purebred classified females was lower than that of unclassified females. Classified females may present greater genetic potential for maternal ability, thus favoring the growth of their offspring.

It was observed that the contemporary group containing males had the highest averages (197.17 $\mathrm{kg}$ ) for the evaluated traits, were $2.37 \%$ heavier than females for W205, and had an ADG value (0.786 $\mathrm{kg} \mathrm{day}{ }^{-1}$ ) that was $2.93 \%$ higher (Table 4). Similar results were obtained by Ferreira et al. (2010) who found an ADG value of $0.823 \mathrm{~kg} \mathrm{day}^{-1}$ for females and $0.861 \mathrm{~kg} \mathrm{day}^{-1}$ for males for the same breed. D160 for males (223.61 days) were 1.04\% higher than that for females.

It was observed that the contemporary group containing the classified female category presented the highest average for W205 (201.78 kg) and ADG values $\left(0.809 \mathrm{~kg} \mathrm{dia}^{-1}\right)$, and was $2.28 \%$ higher in relation to males for W205 (Table 5). The classified female category included purebred females classified by the ACSG, which have under gone evaluations that verified their possible genetic potential for traits of interest for production. The female and male categories were composed of young animals or those without technical approval.

Table 3. Averages of weight adjusted for weaning (W205), average daily gain from birth to weaning (ADG), and number days for the animal to gain $160 \mathrm{~kg}$ from birth to weaning (D160) according to the year of birth.

\begin{tabular}{ccccc}
\hline \multirow{2}{*}{ Year of Birth } & $\mathbf{N}$ & \multicolumn{3}{c}{ Averages } \\
\cline { 3 - 5 } & 2 & W205 (kg) & ADG (kg/day) & D160 (days) \\
\hline $\mathbf{1 9 9 0}$ & 85 & 221.22 & 0.904 & 218.71 \\
$\mathbf{1 9 9 1}$ & 22 & 193.71 & 0.769 & 226.80 \\
$\mathbf{1 9 9 2}$ & 34 & 196.68 & 0.784 & 224.98 \\
$\mathbf{1 9 9 3}$ & 34 & 180.92 & 0.707 & 246.57 \\
$\mathbf{1 9 9 4}$ & 11 & 246.74 & 0.729 & 230.78 \\
$\mathbf{1 9 9 5}$ & 9 & 182.40 & 1.028 & 160.30 \\
$\mathbf{1 9 9 6}$ & 16 & 195.78 & 0.714 & 243.67 \\
$\mathbf{1 9 9 7}$ & & & 0.779 & 222.98 \\
\hline
\end{tabular}

$\mathrm{N}=$ Number of observations.

Table 4. Averages of weights adjusted for weaning (W205), average daily gain from birth to weaning (ADG), and number days for the animal to gain $160 \mathrm{~kg}$ from birth to weaning (D160) according to the animal sex.

\begin{tabular}{ccccc}
\hline \multirow{2}{*}{ Sex } & $\mathbf{N}$ & \multicolumn{3}{c}{ Averages } \\
\cline { 3 - 5 } & & W250 (kg) & ADG (kg/day) & D160 (days) \\
\hline Male & 93 & 197.17 & 0.786 & 223.61 \\
Female & 120 & 192.50 & 0.763 & 225.96 \\
\hline
\end{tabular}

$\mathrm{N}=$ Number of observations. 
Table 5. Averages of weights adjusted for weaning (W205), average daily gain from birth to weaning (ADG), and number days for the animal to gain $160 \mathrm{~kg}$ from birth to weaning (D160) according to the animal category.

\begin{tabular}{ccccc}
\hline \multirow{2}{*}{ Animal Category } & $\mathbf{N}$ & \multicolumn{3}{c}{ Averages } \\
\cline { 3 - 5 } & & W250 (kg) & ADG(kg day $\left.{ }^{-1}\right)$ & D160 (days) \\
\hline Female & 27 & 172.92 & 0.668 & 253.67 \\
Classified Female & 52 & 201.78 & 0.809 & 209.38 \\
Male & 134 & 197.17 & 0.786 & 225.96 \\
\hline
\end{tabular}

$\mathrm{N}=$ Number of observations.

The rainy season, comprised of the spring and summer seasons (September to March), is characterized by having months with high precipitation and high temperatures, which favor the food supply. Conversely, the dry season includes the fall and winter seasons (March to September). The dry season is characterized by dry months with low temperatures and wind, resulting in food shortages. This relationship may explain the higher averages for the animals that were born in the rainy season, which presented higher W205 $(197.18 \mathrm{~kg})$ and ADG values $\left(0.786 \mathrm{~kg} \mathrm{day}^{-1}\right)$ in relation to the animals that were born in the dry season which exhibited $194.06 \mathrm{~kg}$ and $0.771 \mathrm{~kg}$ day $^{-1}$, respectively (Table 6).

The averages for the traits studied ranged from 121.84 to $252.66 \mathrm{~kg}$ for W205, from 0.419 to $1.057 \mathrm{~kg} \mathrm{day}^{-1}$ for $\mathrm{ADG}$, and from 397 to 151 days for D160. The variability among the averages for the characteristics studied reflects the contrast in management for each factor and the environmental conditions in general. Caution with feeding, management, and use of certain breeding herds is essential regarding he differences observed. Moreover, it is also important to consider the individual's genetic potential.

Table 6. Average of weights adjusted to weaning (W205), average daily gains from birth to weaning (ADG), and number of days for the animal to gain $160 \mathrm{~kg}$ from birth to weaning (D160) according to the season of birth.

\begin{tabular}{ccccc}
\hline \multirow{2}{*}{ Season of Birth } & $\mathbf{N}$ & \multicolumn{3}{c}{ Averages } \\
\cline { 3 - 5 } & & W205 (kg) & ADG (kg/day) & D160 (days) \\
\hline Rainy & 134 & 197.18 & 0.786 & 220.16 \\
Dry & 79 & 194.06 & 0.771 & 228.13 \\
\hline
\end{tabular}

$\mathrm{N}=$ Number of observations.

\section{Conclusion}

It is necessary to include properly adjusted environmental factors, such as the cow age at calving, year of birth, season of birth, sex, herd, and diet in the model of analysis of pre-weaning growth traits for results that are more accurate and reliable.

The cow age at calving influenced the preweaning traits studied. Moreover, it is important to verify the ages at which females are put in and pulled out of the productive system in the selection herds. In addition, the animal category revealed the importance of selection.

\section{References}

ASSOCIAÇÃO BRASILEIRA DE SANTA GERTRUDIS - ACSG. A raça. Sorocaba: ACSG, 2018. Disponível em:<http://www.santagertrudis.com.br/texto/ raca/Acesso em: 10 nov. 2018. 
BOCCHI, A. L.; ALBUQUERQUE, L. G. Efeito da idade da vaca e da data juliana de nascimento sobre o ganho médio diário de bezerros de corte no período prédesmame. Arquivo Brasileiro de Medicina Veterinária e Zootecnia, Belo Horizonte, v. 58, n. 4, p. 524-532, 2005. DOI: $10.1590 /$ S0102-09352005000400014

BOCCHI, A. L.; TEIXEIRA, R. A.; ALBUQUERQUE, L. G. Idade da vaca e mês de nascimento sobre o peso ao desmame de bezerros nelore nas diferentes regiões brasileiras. Acta Scientiarum. Animal Sciences, Maringá, v. 26, n. 4, p. 475-482, 2004. DOI: $10.4025 /$ actascianimsci.v26i4.1724

CARDOSO, F. F.; CARDELlinO, R. A.; CAMPOS, L. T. Fatores ambientais que afetam o desempenho do nascimento à desmama de bezerros Angus criados no Rio Grande do Sul. Revista Brasileira de Zootecnia, Viçosa, MG, v. 30, n. 2, p. 326-335, 2001.

CORRÊA, M. B. B.; DIONELLO, N. J. L.; CARDOSO, F. F. Influência ambiental sobre características de desempenho pré-desmama de bovinos Devon no Rio Grande do Sul. Revista Brasileira de Zootecnia, Viçosa, MG, v. 35, n. 3, p. 1005-1011, 2006.

FERRAZ, J. B. S.; ELER, J. P.; RIBEIRO, P. M. T. Genetic study of Santa Gertrudis cattle in Brazil. Livestock Research for Rural Development, Cali, v. 12, n. 2, p.1-8, 2000.

FERREIRA, J. L.; LOPES, F. B.; MARQUES, E. G.; SILVA, M. C.; ASSIS, A. S.; PEREIRA, L. S.; NEPOMUCENO, L. L. Estudo genético quantitativo em características produtivas de bovinos da raça Nelore criados na Região Norte do Brasil. Revista Brasileira de Medicina Veterinária, Viçosa, MG, v. 36, n. 1, p. 1117,2014 .

FERREIRA, J. S. B.; MOURA, A. K. B.; SILVA, M. S.; BARROZO, D.; QUEIROZ, S. A.; THOLON, P. Estimativas de efeitos genéticos e ambientais sobre ganho médio diário de peso em bovinos da raça Santa Gertrudis no período pré-desmama. In: REUNIÃO ANUAL DA SOCIEDADE BRASILEIRA DE ZOOTECNIA, 47., 2010, Salvador. Anais...Salvador: Sociedade Brasileira de Zootecnia, 2010. p. 1-3.

FIALHO, F. R. L.; REZENDE, M. P. G.; SOUZA, J. C.; SILVA, R. M.; OLIVEIRA, N. M.; SILVEIRA, M. V. Performance in preweaning pure and crossbred calves in the Mato Grosso do Sul Pantanal region, Aquidauana, Mato Grosso do Sul State, Brazil. Acta Scientiarum. Animal Sciences, Maringá, v. 37, n. 4, p. 437-442, 2015. DOI: 10.4025 /actascianimsci.v37i4.28345

FRIES, L. A.; BRITO, F. V.; ALBUQUERQUE, L. A. Possíveis consequências na seleção para incrementar pesos às idades-padrão vs. reduzir idades para produzir unidades de mercado. In: REUNIÃO DA SOCIEDADE BRASILEIRA DE ZOOTECNIA, 30., 1996, Fortaleza. Anais... Fortaleza: SBZ, 1996. p. 310-312.

GEMIN, E.; SOUZA, J. C.; SILVA, L. O. C.; MALHADO, C. H. M.; FERRAZ FILHO, P. B. Efeito do meio e da idade da vaca sobre o ganho de peso na fase de cria, recria e os dias para se obter $160 \mathrm{~kg}$ em animais da raça Guzerá. Archives of Veterinary Science, Curitiba, v. 9, n. 1, p. 93-99, 2004.

GUIMARÃES, L. B.; FERRAZ FILHO, P. B.; SOUZA, J. C.; SILVA, L. O. C. Aspectos genéticos e de ambiente sobre pesos pré e pós desmama em bovinos da raça Tabapuã na região pecuária Oeste São Paulo - Paraná. Archives of Veterinary Science, Curitiba, v. 8, n. 1, p. 109-119, 2003.

LOPES, J. S.; RORATO, P. R. N.; WEBER, T.; BOLIGON, A. A.; COMIN, J. G.; DORNELLES, M. A. Parâmetros genéticos e tendências genética e fenotípica para características de crescimento em uma população da raça Brangus. Revista Brasileira de Zootecnia, Viçosa, MG, v. 38, n. 4, p. 662-669, 2009.

LUCHIARIFILHO, A.; MOURÃO, G. B. Melhoramento, raças e seus cruzamentos na pecuária de corte brasileira. Pirassununga: A. Luchiari Filho, 2006. 142p.

MARTINS, G. A.; MARTINS FILHO, R.; LIMA, F. A. M.; LÔBO, R. N. B. Influência de fatores genéticos e de meio sobre o crescimento de bovinos da raça Nelore no estado do Maranhão. Revista Brasileira de Zootecnia, Viçosa, MG, v. 29, n. 1, p. 103-107, 2000. DOI: 10.1590/ S1516-35982000000100014

OXFORD, E. L.; BROWN JÚNIOR, A. H.; JOHSON, B. Z.; TABLER, G. T.; KUTZ, B. R. Preweaning performance, heterosis and direct and maternal breed effects in Angus, Hereford, Redpoll, Santa Gertrudis, and reciprocal-cross calves. The Professional Animal Scientist, Champaingn, v. 25, n. 5, p. 529-535, 2009. DOI: $10.15232 / \mathrm{S} 1080-7446(15) 30754-3$

PEREIRA, A. M. V. S.; MUNIZ, C. A. S. D. Efeitos ambientais sobre características pré-desmama em bovinos da Raça Nelore Mocha. Semina: Ciências Agrárias, Londrina, v. 34, n. 1, p. 359-366, jan./fev. 2013. DOI: $10.5433 / 1679-0359.2013 v 34 n 1 p 359$

RIBEIRO, S.; ELER, J. P.; BALIEIRO, J. C. C.; FERRAZ, J. B. S.; PEDROSA, V. B.; MATTOS, E. C. Influência da interação genótipo $\mathrm{x}$ ambiente sobre $\mathrm{o}$ peso à desmama em bovinos da raça Nelore. Arquivo Brasileiro de Medicina Veterinária e Zootecnia, Viçosa, MG, v. 61, n. 3, p. 668-675, 2009. DOI: 10.1590/S010209352009000300021 
SANTOS, G. C. J.; LIRA, T. S.; PEREIRA, L. S.; LOPES, F. B.; FERREIRA, J. L. Efeitos não genéticos sobre características produtivas em rebanhos Nelore criados na região norte do Brasil. Acta Veterinária Brasílica, Mossoró, v. 5, n. 4, p. 385-392, 2011.

SARMENTO, J. L. R.; PIMENTA FILHO, E. C.; RIBEIRO, M. N.; MARTINS FILHO, R. Efeitos ambientais e genéticos sobre o ganho em peso diário de bovinos Nelore no Estado da Paraíba. Revista Brasileira de Zootecnia, Viçosa, MG, v. 32, n. 2, p. 325-330, 2003.

TAYLOR, G. J. Factors affecting the production and reproduction performance of tropically adapted beef cattle in southern Africa. 2006. $\mathrm{PhD}$ (Agriculture) University of Pretoria, Pretoria, South Africa.
TEIXEIRA, R. A.; ALBUQUERQUE, L. G. Efeitos ambientais que afetam o ganho de peso pré-desmama em animais Angus, Hereford, Nelore e mestiços Angus-Nelore e Hereford-Nelore. Revista Brasileira de Zootecnia, Viçosa, MG, v. 32, n. 4, p. 887-890, 2003. DOI: $10.1590 / \mathrm{S} 1516-35982003000400014$

THOLON, P.; FERNANDES, R. C.; MOURA, A. K. B.; OLIVEIRA, K. P.; BARROZO, D.; QUEIROZ, S. A. Análise de fatores ambientais e estimativa de parâmetros genéticos de características de desempenho ponderal em bovinos da raça Santa Gertrudis. In: REUNIÃO ANUAL DA SOCIEDADE BRASILEIRA DE ZOOTECNIA, 47., Salvador. Anais... Salvador: Sociedade Brasileira de Zootecnia, 2010. p. 1-3. 